\title{
Sovereignty and Constitutionalism in International Law
}

\author{
BARDO FASSBENDER *
}

\section{INTRODUCTION}

$\mathrm{T}$ HE IDEA OF sovereignty is amongst the oldest concepts of modern international law; it accompanied and fostered the rise of the modern state. The 'sovereign state' is still the standard member of the international community. International law endeavours to maintain a uniform global system of sovereign states, and therefore sometimes generously attributes sovereignty to entities whose independent statehood is doubtful not only in actual, but also in legal terms. Throughout its long history, the concept of sovereignty has proved highly adaptable. It has survived many premature obituaries, and the charge that it stands in the way of a system of international governance adequate to ensure the future existence of humanity. Through the centuries, it has acquired an almost mythical quality. ${ }^{1}$ Sovereignty is usually claimed, or rejected, in times of political crisis, party strife, war and civil war. Although (or perhaps just because) its contours are so blurred, it played, and continues to play, a prominent role in modern constitutional and international legal theory, as well as in politics.

We are concerned here with sovereignty as a legal notion and concept, but as such it integrates a political dimension which paradoxically often defies legal control. In other words, sovereignty as a legal concept is characterised by an uneasy tension between an effort legally to define, and therefore limit, the powers of the person or body who claims to be sovereign, and that sovereign's (at least occasional) efforts to evade the control exerted by legal rules and procedures, or to change the law according to his

\footnotetext{
* This paper is dedicated, as a sign of gratitude, to my dear teacher Ernst Portner, Professor of Modern History at the University of Bonn, who first spoke to me of sovereignty.

${ }^{1}$ See L Henkin, 'The Mythology of Sovereignty', in RStJ Macdonald (ed.), Essays in Honour of Wang Tieya (The Hague, Martinus Nijhoff, 1993.), 351.
} 
interests. The latter aspect refers us back to the origins of the concept, when sovereignty was all about claims-the assertion of a right or an alleged right, or of something ('sovereign power') as a fact. Since the French jurist and philosopher Jean Bodin introduced the notion into the theory of state in the sixteenth century, it has been resorted to as an argument in a concrete political struggle-as a description of what was desired or aspired to rather than of what really existed. At the beginning of the modern European system of states, the notion was used in order to establish and defend the independence of the French King from the Pope and the Emperor of the Holy Roman Empire, and the supremacy of his orders over those of particularistic powers in what became France. From time to time, this original meaning, political in nature, comes to the surface, and more so in the international affairs of a state than 'at home' where (at least in the Western world) constitutional restraints are more fully developed. To fail to appreciate this untamed side of sovereignty is to misunderstand the concept.

\section{SOVEREIGNTY IN THE 'INTERNATIONAL LAW OF COEXISTENCE'}

According to a widely shared view, sovereignty has two complementary and mutually dependent dimensions: Within a state, a sovereign power makes law with the assertion that this law is supreme and ultimate, i.e. that its validity does not depend on the will of any other, or 'higher', authority. Externally, a sovereign power obeys no other authority. As the modern state began to develop, the internal dimension of sovereignty addressed the problem of 'intermediate' powers within a certain territory, independent in a legal or actual sense, which an emerging 'central' power sought to subjugate. The external claim to sovereignty was directed against powers outside the territory. ${ }^{2}$ This latter dimension is also referred to as 'sovereignty in international law' or 'independence'. ${ }^{3}$

列 2 For the history of the concept of sovereignty, see (Cambridge, Cambridge University Press, 1986), H Quaritsch, Staat und Souverant: Entstehung und Grundlagen (Frankfurt/Main, Athenäum, 1970), id., Souveranitud Entwicklung des Begriffs in Frankreich und Deutschland vom 13. J Thriam, Jr., History of the Duncker \& Humblot, 1986). Of the older literature, I mention CE Merity Press, 1900) (Studies Theory of Sovereignty since Rousseau (New York, Columbia University Press, in History, Economics and Public Law, vol. XII no. 4). For the etymology of the word, serfe, vol. Klippel \& H Boldt, 'Souveränität', in O Brunner et al. (eds.), Geschichtliche Grundbegifict the history of 6 (Stuttgart, Klett-Cotta, 1990) 98. For a fresh look of a political scientrum of mechanisms of sovereignty in political practice, offering an analysis of a whole spectrum of meentury, see SD Krasner, intervention made use of by the major powers since the nineteenth cen Press, 1999).

Sovereignty: Organised Hypocrisy (Princeton, NJ, Princeton University Press, 199. ICJ Reports 3 See, e.g., Interpretation of Peace Treaties with Bulgaria, Hungary and Romania, C C Reports
(1950) 65 at 98,99 et seq. (sep. opinion Zoričić): sovereign equality as 'the corollary of independence'. 
The modern centralised territorial state appeared in Europe due essentially to the fact that the idea of (internal) sovereignty, as propounded by political philosophers and legal scholars, had been generally accepted in state practice. The entire legal order, including the powers of 'public' persons and communities subordinated to the central authority, was constructed as deriving from the will of the sovereign. The medieval concept of personal jurisdiction was augmented by a territorial jurisdiction, consolidating fragmented regal rights into a unified sovereign power as a source of comprehensive and exclusive authority. Externally, sovereignty was understood as legal independence from all 'foreign' powers, and as impermeability-protecting the relevant territory against all outside interference. The medieval universalism of the Empire and the Roman Catholic Church was superseded by the new concept of the 'international legal community' proclaimed by Spanish theologians. ${ }^{4}$

According to the doctrine of sovereignty prevailing in the nineteenth and the better part of the twentieth century, states were only bound by those rules of law to which they had agreed, either by the conclusion of treaties or customarily. There existed a presumption in favour of 'unrestrained sovereignty'. In the Lotus case, the Permanent Court of International Justice held that 'restrictions upon the independence of States cannot . . be presumed'. ${ }^{5}$

The jus ad bellum, or right to go to war, had been claimed by factually independent powers long before the concept of sovereignty was formulated;

'but just as it was consolidated by the rise of the modern state, so it was freed from external moral and theological sources of restraint and made into the most basic of all the rights of the sovereign state ... In the international law of the modern international system it was a legal right ... [S]tates clung tenaciously to this right, believing it to be fundamental to their sovereignty. ${ }^{\prime}{ }_{6}$

Wolfgang Friedmann identified the classical system of international law as a 'law of coexistence'. This law he juxtaposed with a newer 'international law of co-operation' the beginnings of which he recognised in the period between the two World Wars of the twentieth century:

\footnotetext{
${ }^{4}$ See A Verdross \& B Simma, Universelles Völkerrecht $3^{\text {rd }}$ edition (Berlin, Duncker \& Humblot, 1984), at 8 et seq., 11-3; A Nussbaum, A Concise History of the Law of Nations (New York, The Macmillan Company, rev. ed. 1954), at 79-91.

${ }^{5}$ See Lotus judgment, PCIJ, Series A, No. 10 (1927), at 18: 'International law governs relations between independent States. The rules of law binding upon States therefore emanate from their own free will as expressed in conventions or by usages generally accepted as expressing principles of law and established in order to regulate the relations between these coexisting independent communities or with a view to the achievement of common aims. Restrictions upon the independence of States cannot therefore be presumed.'

${ }^{6}$ See Hinsley, above n 2, at 230.
} 


\section{Sovereignty and Constitutionalism in International Law}

'This move of international society, from an essentially negative code of rules of abstention to positive rules of co-operation . . . is an evolution of immense significance for the principles and structure of international law."

The principle of non-intervention in the internal affairs of other states, the rule that in the territory of a foreign state sovereign power may not be exercised, ${ }^{8}$ and the concept of state (or 'sovereign') immunity ${ }^{9}$ are primary examples of Friedmann's 'rules of abstention'. The principle of external sovereignty determined the overall structure and virtually the entire substance of the international law of coexistence. ${ }^{10}$ Max Huber's famous definition of sovereignty in the Island of Palmas arbitral award (1928) is a perfect expression of the negative or exclusive quality characteristic of the concept in the period of 'coexistence':

'Sovereignty in the relations between states signifies independence. Independence in regard to a portion of the globe is the right to exercise therein, to the exclusion of any other state, the functions of a state. ${ }^{11}$

An individual state's internal order was not only shielded from intervention by other states but also from any uninvited 'intrusion' by international law. The concept of the 'impermeability of the state' protected a domestic legal order like a shield through which international law could not pass. ${ }^{12} \mathrm{It}$ led to Heinrich Triepel's doctrine of 'dualism'-a strict separation of international and domestic law-, ${ }^{13}$ and also to the idea that in its external relations a state should only speak with 'one voice', namely that of the central government and its minister of foreign affairs.

\footnotetext{
7 See W Friedmann, The Changing Structure of International Law (London, Stevens \& Sons, $1964)$, at 62 . In 1970 , the General Assembly proclaimed the duty of states 'to co-operate with one another, irrespective of the differences in their political, economic and social systems, ... in order to maintain international peace and security and to promote international economic stability and progress, the general welfare of nations and international co-operation free from discrimination based on such differences' ('Friendly Relations Declaration', below n 49).

${ }^{8}$ See Lotus judgment, above n 5, at p. 18 et seq.: '[A State] may not exercise its power in any form in the territory of another State. In this sense jurisdiction is certainly territorial; it cannot be exercised by a State outside its territory except by virtue of a permissive rule derived from international custom or from a convention.'

9 See, eg, I Brownlie, Principles of Public International Law $5^{\text {th }}$ edition (Oxford, Clarendon Press, 1998), at 327: Sovereign immunity rests on the principle, 'expressed in the maxim par in parem non habet jurisdictionem [and] concerned with the status of equality attaching to the independent sovereign, [that] legal persons of equal standing cannot have their disputes settled in the courts of one of them'.

${ }_{10}$ See A Bleckmann, Völkerrecht (Baden-Baden, Nomos, 2001), at 60-71.

${ }^{11}$ For text of the award, see 22 American Journal of International Law (1928) 867 at 875; 2 UNRIAA 829 at 838 (emphasis added).

12 See A Bleckmann, Grundgesetz und Völkerrecht (Berlin, Duncker \& Humblot, 1975), at 264-73.

${ }_{13}$ See H Triepel, Völkerrecht und Landesrecht (Leipzig, CL Hirschfeld, 1899), and id., 'Les rapports entre le droit interne et le droit international', 1 Recueil des Cours: Collected Courses of the Hague Academy of International Law [hereinafter Recueil des Cours] (1923-I) 77.
} 
International law was considered as a body of norms exclusively regulating relationships between states, so that only states could be subjects of international law. It was generally denied that the individual could enjoy such status,${ }^{14}$ and only in the age of the League of Nations was the possibility of international legal personality of international organisations composed of states reluctantly accepted. ${ }^{15}$

In the nineteenth century, the ideas of sovereignty, the nation state and imperialism had been joined, reinforcing each other and leading to an 'anarchy of sovereignty'. ${ }^{16}$

'[T] he concept of sovereignty, being made to serve the state or the nation regarded as an absolute end, was interpreted as justifying the use of absolute power or symbolising the actual possession of it. ${ }^{17}$

Only in these circumstances, after the decline of the doctrine of natural law, was a claim to a power unrestrained by law derived from the concept of sovereignty. The emphasis shifted from building and perfecting an effective state authority to a fierce competition with other nations. 'Sovereign nation states', constructed and understood as closed, self-contained entities facing one another, fought over political, economic and military power. To preserve, strengthen or, if lost or impaired, reestablish 'national sovereignty' became the ultimate foreign policy goal, and thus thinking in terms of sovereignty was intimately linked with power politics. In this period, 'sovereignty in international affairs could never be conceived apart from a confusion of it with arbitrary power'. ${ }^{18}$ A state's sovereignty was not conceived of as a power to be used towards a 'common good' of the international community but as a subjective right to be exercised in that state's own interest. International law was essentially bilateral, and was not considered to go beyond the correlative rights and obligations of its subjects. ${ }^{19}$ It was only later that states came to realise, and acknowledge, a need for cooperation for the furtherance of community goals, and to assume that all members of the international community should take into account the valid interests of the other members in exercising their respective sovereignty. ${ }^{20}$

${ }^{14}$ See Verdross \& Simma, above n. 4, at 255 et seq., 264, and Friedmann, above n. 7, at $232-42,245-9$.

1s See B Fassbender, 'Die Völkerrechtssubjektivität internationaler Organisationen', 37 Österreichische Zeitschrift für öffentliches Recht und Völkerrecht (1986), 17 at 18-25.

${ }^{16}$ See O Kimminich, Einführung in das Völkerrecht $6^{\text {th }}$ edition (Tübingen, Francke, 1997), at 66.

17 See Hinsley, above n. 2, at 217.

18 See G Butler, 'Sovereignty and the League of Nations', 1 British Year Book of International Law (1920-1) 35 at 42.

19 See B Simma, 'From Bilateralism to Community Interest in International Law', 250 Recueil des Cours (1994) 217 at 230-3.

${ }^{20}$ For an exposition of shifts in the understanding of external sovereignty 'in the age of cooperative international law', see A Bleckmann, 'Commentary on Art. 2(1) of the UN Charter', in B Simma (ed.), The Charter of the United Nations: A Commentary (Oxford, Oxford University Press, and Munich, CH Beck, 1994), 77 at 84-7. 


\section{Sovereignty and Constitutionalism in International Law}

Understandably, in retrospect, the idea of sovereignty was seen as having supported political developments eventually leading to the two world wars. The idea entered a state of crisis in the 1920s, and in particular after 1945, when legal science reacted to the adoption of the UN Charter by gradually redefining sovereignty and advancing the notion of solidarity, of all member states of the international community. In Western Europe, cooperation under the umbrella of a 'supranational' organisation replaced national sovereignty as the central theme of international relations. The new approach found a characteristic expression in the preamble of the 1951 Treaty of Paris:

'The Heads of Government and State,

... Considering that world peace can be safeguarded only by creative efforts commensurate with the dangers that threaten it,

... Resolved to substitute for age-old rivalries the merging of their essential interests; to create, by establishing an economic community, the basis for a broader and deeper community among peoples long divided by bloody conflicts, and to lay the foundations for institutions which will give direction to a destiny henceforward shared,

Have decided to create a European Coal and Steel Community ... ${ }^{21}$

After 1945, sovereignty was only emphasised by 'latecomers' (the new states which, having emerged from decolonisation, sought to consolidate their fragile independence) and states feeling unsure of themselves (in particular the Soviet Union and its satellite states). ${ }^{22}$

\section{EQUALITY OF STATES}

The legal principle of equality of states is so closely connected with that of sovereignty that the fusion in the UN Charter of the two terms into one ('sovereign equality', Art. 2(1)) suggested itself. But still, the history of the concept of equality in modern international law cannot be told as a similar story of rise and fall. It seems that, compared to sovereignty, the equality of states was always more disputed in state practice as well as legal doctrine. This is understandable because sovereignty was a principle defended by all states, including the powerful, which often played a leading role in this regard, whereas equality was generally invoked by smaller states (and their

\footnotetext{
${ }^{21}$ Treaty of Paris Establishing the European Coal and Steel Community, 18 April 1951, preamble, 261 UNTS 140. For the historical context, see, e.g., B Fassbender, 'Zur staatlichen Ordnung Europas nach der deutschen Einigung', 46 Europa Archiv (1991) 395 at 397.

${ }^{22}$ See, e.g., N Mugerwa, 'Subjects of International Law', in M Sørensen, Manual of Public International Law (London, Macmillan, and New York, St Martin's Press, 1968), 247 at 253-5; RP Anand, 'Sovereign Equality of States in International Law', 197 Recueil des Cours (1986) 9; Akademie der Wissenschaften der UdSSR-Rechtsinstitut, Völkerrecht (L Schultz transl., Hamburg, Hansischer Gildenverlag Joachim Heitmann, 1960), at 91-109.
} 
lawyers) against the actions, aspirations and presumptions of a mighty neighbour state or the 'Great Powers' together.

As a principle of modern international law, the equality of (Christian) states was recognised in the Peace of Westphalia of 1648; regardless of their Catholic or Protestant faith, and of their monarchical or republican form of government, their statehood was equally recognised and protected. The treaties formally bade farewell to the medieval conception of a society of states organised hierarchically, i.e. on the basis of inequality. ${ }^{23}$ At the same time, this recognition of equality resulted from a political compromise in favour of peace-an agreement henceforth to ignore, from a legal point of view, certain actual differences which before had been of legal relevance.

The most widely read book on international law in the eighteenth century, written by Emer de Vattel-a foremost representative of the natural law school of the period-was based on the idea of a société des nations, the members of which enjoy an equal status. In his introduction, Vattel said: 'A dwarf is as much a man as a giant is; a small Republic is no less a sovereign state than the most powerful kingdom. ${ }^{24}$ In the age of Enlightenment the idea of the equality of states was based on an analogy with the 'natural' status of men which, a century earlier, Thomas Hobbes had described as follows: 'Nature hath made men so equall, in the faculties of body, and mind'. ${ }^{25}$ In the same spirit of natural law, the Virginia Bill of Rights of 1776 proclaimed in its very first sentence that '[a]ll men are by nature equally free and independent and have certain inherent rights ... ${ }^{26}$ In accordance with the said analogy, the Articles of Confederation between the thirteen United States of America of 1777 then provided that '[i]n determining questions in

${ }^{23}$ See L Gross, 'The Peace of Westphalia, 1648-1948', 42 American Journal of International Law (1948) 20 at 33, and B Fassbender, 'Die verfassungs- und völkerrechtsgeschichtliche Bedeutung des Westfälischen Friedens von 1648', in I Erberich et al. (eds.), Frieden und Recht (Stuttgart, Richard Boorberg, 1998) 9 at 21-33.

${ }_{24}$ See E de Vattel, Le droit des gens, ou principes de la loi naturelle, appliqués à la conduite et aux affaires des Nations et Souverains, vol. 1 (London, Tutior, 1758), at 11. Translated as The Law of Nations, or the Principles of Natural Law, applied to the Conduct and to the Affairs of Nations and of Sovereigns by CG Fenwick ('The Classics of International Law', Washington, DC, The Carnegie Institution of Washington, 1916); quotation at 7. For a summary of Vattel's principal ideas, see Nussbaum, above n. 4, at 156-64, and E Reibstein, Völkerrecht: Eine Geschichte seiner Ideen in Lehre und Praxis, vol. 1 (Freiburg and Munich,
Karl Alber, 1958) at 571-609.

${ }^{25}$ See T Hobbes, Leviathan, or The Matter, Forme, \& Power of a Common-Wealth Ecclesiasticall and Civill (London, A Crooke, 1651, CB Macpherson (ed), London, Pelican Books, 1968), part 1, ch. XIII. For the history of the notion of equality in the modern age, see O Dann, 'Gleichheit', in Geschichtliche Grundbegriffe (above n. 2), vol. 2 (1975), at
997-1046.

${ }^{26}$ For text, see SE Morison (ed.), Sources and Documents Illustrating the American Revolution 1764-88 and the Formation of the Federal Constitution $2^{\text {nd }}$ edition (London, Oxford University Press, 1929) at 149. For an explanation of the historical and philosophical context, see G Kleinheyer, 'Grundrechte, Menschen - und Bürgerrechte, Volksrechte', in Geschichtliche Grundbegriffe (above n. 2), vol. 2 (1975), at 1047-82. 


\section{Sovereignty and Constitutionalism in International Law}

the United States in Congress assembled, each state shall have one vote'. ${ }^{27}$ Here, the idea of equality in legal status was translated into equal voting power.

Inspired by Vattel and the thinking of the Enlightenment, the theorists of the French Revolution also equated states with individuals having the same rights and duties. In a representative statement, the Abbé Grégoire said in his draft declaration of the rights of peoples of April 1793:

'...2. Peoples are independent of each other and sovereign, irrespective of the number of individuals they comprise and the extent of the territory which they occupy. 3. One people has to act in relation to others as it wants others to act in (the other. ${ }^{28}$

As Wilhelm Grewe concluded, the ideas of the Revolution about the law of nations were a precise reflection of its philosophy of individualism at the level of inter-state relations, ${ }^{29}$ a philosophy that remained influential. ${ }^{30}$ In this context, the principle of equality of states was related to, and partly deduced from, the ideas of democracy, popular sovereignty and the selfdetermination of peoples, and today it is still situated in that same conceptual field or milieu.

In the nineteenth century, the principle was upheld as a matter of law, but beginning with the defeat of France by the anti-Napoleonic coalition and the Congress of Vienna (1814-15) the 'Great Powers' actually exercised a hegemony over the other European states. It was they that took the decisions they deemed necessary for maintaining the European order and the balance of power in Europe. ${ }^{31}$ Those powers were called puissances à intérêts généraux because they were thought to be concerned with all international

${ }_{28}^{27}$ Art. V para. 4. For text, see Sources and Documents, ibid. 178 at 179.

28 ' $\ldots 2^{\circ}$ Les peuples sont respectivement indépendants et souverains, quel

d'individus qui les composent et l'étenduntépendants et souverains, quel que soit le nombre à l'égard des autres comme il désire qu' du territoire qu'ils occupent. $3^{\circ}$ Un peuple doit agir homme, un peuple le doit aux autres'. See WG Gre à son égard; ce qu'un homme doit à un Sources Relating to the History autres'. See WG Grewe (ed.), Fontes Historiae Iuris Gentium: de Gruyter, 1988), at 660. See af the Law of Nations, vol. 2 (Berlin and New York, Walter Assembly, Comte de Volney, of 18 May 1790 ; reprintaration of the member of the National de la révolution française sur le déveloy 1790; reprinted in B Mirkine-Guetzévitch, 'L'influence 22 Recueil des Cours 22 (1928) 299 at 309. 29 See WG Grewe, The (1928) 299 at 309.

1984), at 415.

${ }^{30}$ Consider only the preamble of the UN Charter which speaks of 'the equal rights of men and women and of nations large and small'.

International Law from 1814 to 1920 (Wuropean Concert', see K Wolfke, Great and Small Powers in Wroclaw, 1961), at 9-49 1814 to 1920 (Wroclaw, Société des Sciences et des Lettres de Konzerts, 1886-1914 (Vienna, Verlas Kollektivaktionen der Mächte des Europäischen 1988). For the notion of hegemony der Osterreichischen Akademie der Wissenschaften, Hegemonie. Ein Buch von führenden as a legal term, see, in particular, H Triepel, Die See also A Randelzhofer, 'Great Powers', in R $2^{\text {nd }}$ edition (Stuttgart, W Kohlhammer, 1943). International Law (Amsterdam, Elsevier, 1995), 618. 
affairs even if their immediate interests were not affected. ${ }^{32}$ In a tone of British self-assurance, the 1947 edition of Oppenheim's treatise still read:

'Arrangements made by the body of the Great Powers tend to gain the consent or the acquiescence of the minor States. The Great Powers are the leaders of the Family of Nations, and every advance of the Law of Nations during the past has been the result of their political hegemony ....33

On the other hand, smaller powers were able to participate on an equal basis in international conferences on technical matters (such as postal services) and the codification of international law, the number of which grew rapidly in the second half of the century. ${ }^{34}$

Dickinson concluded in 1920 that the 'equality of states' was actually the expression of two distinct legal principles, namely 'the principle of equal protection of the law or equality before the law, and that of equality of rights and obligations or simply equality of rights'. To him, the first principle was 'absolutely essential to a stable society of nations', whereas the second 'has never been anything more than an ideal' and was even dangerous when applied to the participation of states in international organisations. ${ }^{35}$ State practice of the time does not suggest that anything more was protected than an equality of formal legal status, in particular the same political independence and territorial integrity, and the same freedom to act in a legally relevant way on the international plane. ${ }^{36}$

As far as 'procedural equality' in international law was concerned, i.e. equality in representation, voting, and active participation in international organisations and conferences, the Covenant of the League of Nations (1919) made it clear that it was only guaranteed to a limited extent. On the one hand, the Covenant confirmed the principle of equality of states by opening the League to '[a]ny fully self-governing State' (and even any such 'Dominion or Colony'), ${ }^{37}$ and by making the unanimity rule the basis of its voting arrangements. ${ }^{38}$ As a subcommittee of the League's Assembly

\footnotetext{
${ }^{32}$ See H Mosler, Die Grossmachtstellung im Völkerrecht (Heidelberg, Lambert Schneider, 1949), at 22 et seq.

${ }^{33}$ See L Oppenheim, International Law: A Treatise, vol. $16^{\text {th }}$ edition (London, Longmans, Green \& Co., 1947, H Lauterpacht, ed.), at 244. The eighth edition (1955) retained only the first sentence of this statement (at 275).

${ }^{34}$ See Wolfke (above n. 31), at 47-78.

${ }^{35}$ See E de W Dickinson, The Equality of States in International Law (Cambridge, Mass., Harvard University Press, 1920), at 334-6.

${ }^{36}$ Cf. the formulation in Art. 4 of the Montevideo Convention on the Rights and Duties of States of 26 December 1933 (28 American Journal of International Law (1934), Suppl., 75 at 76): 'States are juridically equal, enjoy the same rights, and have equal capacity in their exercise. The rights of each one do not depend upon the power which it possesses to assure its [sic] exercise, but upon the simple fact of its existence as a person under international law.' ${ }^{37}$ See Art. 1(2) of the Covenant.

${ }^{38}$ See Art. 5 of the Covenant: 'Except where otherwise expressly provided in this Covenant or by the terms of the present Treaty, decisions at any meeting of the Assembly or of the Council shall require the agreement of all the Members of the League represented at the meeting.'
} 


\section{Sovereignty and Constitutionalism in International Law}

declared, ' $[t]$ he essential characteristic of the unanimity rule . . . is that it serves as the safeguard of the sovereignty of states. ${ }^{39}$ But at the same time, and more importantly, the existence of leading powers and their special role was given a formal legal expression-the 'Principal Allied and Associated Powers' were assigned permanent seats in the League's Council. ${ }^{40}$

'The Paris Conference of 1919, confirming and consolidating the leading position of the great Powers, which stretched back to the first years of the previous century, marked the close of an important stage in the development of . . . international law. ${ }^{31}$

This did not happen by chance. Unlike a legal system which is without any permanent institutional structure, a constitutional order such as that built by the Covenant cannot ignore actual differences among its constituent members which bear strongly on the political and legal course the community is steering. However, the four or five major powers elevated to the rank of permanent members never constituted a majority of the Council. The number of non-permanent members was raised from four originally, to six in 1922, nine in 1926, ten in 1933 and eleven in 1936. An observer critically noted in retrospect: '[I]t was the unworkable nature of the doctrine of equal rights that caused power, like water, to find its level, and the real decisions to be made outside Geneva. ${ }^{42}$

\section{SOVEREIGNTY SINCE 1945: THE CONCEPT OF 'SOVEREIGN EQUALITY'}

Since the United Nations Organisation was founded in 1945, the traditional notion of sovereignty has experienced a profound modification and limitation. Step by step, and following the experience of a steadily increasing interdependence of states, the 'sovereign state' of the past turned into a (primarily territorially defined) organisation with a large number of international legal obligations (arising with, without, and even against its will)an organisation which in the complex structure of the universal legal order is endowed with, comparatively, the highest degree of autonomy. In 1934, Hermann Heller still referred to sovereignty as a 'highest, exclusive, irre-

\footnotetext{
39 See Records of Second Assembly, Meetings of Committees, I, pp. 177 et seq., quoted in DP Myers, 'Representation in League of Nations Council', 20 American Journal of International

${ }^{40}$ See Art. 4(1) of the Covenant.

${ }^{41}$ See Wolfke (above n. 31), at 125 . ${ }^{42}$ See HW Briggs, 'Power Politics and
International Law (1945) 664 at 670.
} 
sistible and independent power' of a state..$^{43}$ Today, such a power no longer exists, neither in a factual nor in a legal sense.

\section{A. 'Sovereign Equality' in the UN Charter}

The Charter of the United Nations does not speak of 'sovereignty' as such but proclaims the 'principle of the sovereign equality' of all members of the UN (Article 2(1)). By referring to the concept of sovereignty, it seems, those drawing up the Charter sought to link their project to earlier periods of the international legal order, and make it appear less of a break with the past than it actually was. However, the phrase 'sovereign equality', newly introduced into international law by the Charter, is already a signal indicating profound change. 'Sovereign equality' is not simply the addition of 'equality' and 'sovereignty' of states in a traditional sense. It is not an expression which would have transposed the old concepts into the Charter. Instead, the year 1945 constitutes a deep dividing line in the history of sovereignty. PreCharter explanations and definitions of sovereignty must be approached carefully in order to evaluate their relevance in the age of the UN.

The notion of 'sovereign equality' first appeared in the Moscow Declaration (or 'Declaration on General Security') of 30 October 1943, in which the governments of the United States, the United Kingdom, the Soviet Union and China pronounced

' $[t]$ hat they recognise the necessity of establishing at the earliest practicable date a general international organisation, based on the principle of the sovereign equality of all peace-loving states, and open to membership by all such states, large and small, for the maintenance of international peace and security. ${ }^{44}$

In Committee I/1 of the San Francisco Conference, '[s]everal delegates expressed disapproval of the phrase sovereign equality and suggested replacing it with juridical equality or some similar term' because other parts of the Charter (i.e., the provisions concerning the Security Council) would not be consistent with the concept of equal sovereignty. ${ }^{45}$ The rapporteur of the committee felt that

${ }^{43}$ See H Heller, Staatslehre $6^{\text {th }}$ edition (Leiden, AW Sijthoff's, 1934, Tübingen, JCB Mohr, 1983), at 246 and 278, respectively: 'Die Staatsgewalt ist souverän, das heisst sie ist auf ihrem Gebiete oberste, ausschliessliche, unwiderstehliche und eigenständige Macht.'

${ }^{44}$ Paragraph. 4. For text, see UNYB 1946-47 at 3. For the drafting history of Art. 2(1) UN Charter, see B Fassbender, 'Commentary on Art. 2(1) of the UN Charter', in Simma, The Charter of the United Nations (above n. 20), $2^{\text {nd }}$ ed. 2002. The phrase 'sovereign equality' apparently was first used in the context of inter-American relations before and in World War II; see RA Klein, Sovereign Equality Among States: The History of an Idea (Toronto, University of Toronto Press, 1974), chapters 5 and 6, in particular pp. 104, 108, 113.

${ }_{45}$ See Summary Report of Eighth Meeting of Committee I/1, 17 May 1945, in VI United Nations Conference on International Organization [UNCIO] at 310. See also Summary Reports of Seventh Meeting, 16 May 1945, ibid. 303 at 304, and of Eleventh Meeting, 4 June 1945, ibid. 331 et seq. 


\section{Sovereignty and Constitutionalism in International Law}

'Article 1 ['Purposes'] should be re-worded to include the three ideas that (1) members are juridically equal, (2) all enjoy the rights inherent under [sic] sovereignty, and (3) they all should act in accordance with their duties under the Charter; Article 2 ['Principles'] should be eliminated. . . ${ }^{96}$

However, the drafting subcommittee decided to leave the text of Chapter II (the later Article 2), paragraph 1 as proposed by the Four Sponsoring Governments. ${ }^{47}$ In its report of 1 June 1945 the subcommittee included an interpretive statement that was an amalgam of the various suggested amendments to Chapter II, paragraph 1:

'The Subcommittee voted to keep the terminology, 'sovereign equality,' on the assumption and understanding that it conveys the following:

(1) That states are juridically equal;

(2) That they enjoy the rights inherent in their full sovereignty;

(3) That the personality of the state is respected, as well as its territorial integrity and political independence;

(4) That the state should, under international order, comply faithfully with its international duties and obligations. ${ }^{38}$

Because of its careful preparation and adoption by consensus, the 'Friendly Relations Declaration' of the UN General Assembly of $1970^{49}$ can be relied upon almost as a text enjoying binding force. ${ }^{50}$ Among the seven principles considered to constitute the groundwork of international law in the era of the United Nations, the 'principle of sovereign equality of States' is set forth as the penultimate. It is significant that the principle is only mentioned after five fundamental duties of states arising from their membership in the international community have been stated (namely the duties to refrain from the threat or use of force, to settle disputes by peaceful means, not to intervene in domestic matters of other states, to cooperate with other states, and to promote the realisation of the principle of equal rights and self-determination of peoples), and that it is followed by the statement of yet another duty (to fulfil international obligations in good faith). The principle of sovereign equality is explained as follows:

'All States enjoy sovereign equality. They have equal rights and duties and are equal members of the international community, notwithstanding differences of an economic, social, political or other nature.

${ }^{46}$ Ibid. (Eighth Meeting), at 311.

47 See Text of Chapter II as Agreed upon by the Drafting Committee, 28 May 1945; VI UNCIO at 687.

${ }_{48}$ See Report of Rapporteur of Subcommittee I/1/A to Committee I/1: Chapter II, 1 June 1945; VI UNCIO at 717 et seq.

${ }^{49}$ Annex to GA Res. 2625 (XXV). For text, see UNYB 1970 at 788.

so See the Nicaragua judgment of the International Court of Justice, ICJ Reports 1986, 14 at $107:$ '. . . the Declaration ... which set out principles which the General Assembly declared to be 'basic principles' of international law'. 
In particular, sovereign equality includes the following elements:

(a) States are juridically equal;

(b) Each State enjoys the rights inherent in full sovereignty;

(c) Each State has the duty to respect the personality of other States;

(d) The territorial integrity and political independence of the State are inviolable;

(e) Each State has the right freely to choose and develop its political, social, economic and cultural systems;

(f) Each State has the duty to comply fully and in good faith with its international obligations and to live in peace with other States.'

In conformity with Article 5 of the 1949 Draft Declaration on Rights and Duties of States elaborated by the UN International Law Commission, ${ }^{51}$ the principle of sovereign equality is primarily understood as assuring states a right to equality in law. The specification, which opens with the words 'in particular' to express its non-exhaustive character, then essentially repeats the interpretive statement of the San Francisco Conference. Compared to that statement, only the right defined under (e) was added, and the duty to live in peace with other states under (f). Whereas the latter simply reinforces the first two principles of the Friendly Relations Declaration, the former is a consequence of the recognition of the right to self-determination of peoples in the era of decolonisation-a right which is not lost once a people has established its own independent state. However, the inclusion of the right stated under (e), a right the existence of which was simply taken for granted in the framework of the international law of coexistence, shows that in the first two-and-a-half decades after 1945 the traditional understanding of what constituted the domaine reserve of states, closed to an international exertion of influence, had considerably changed.

Apart from accentuating the legal equality of states, the Declaration's definition of equal sovereignty is as unspecific as that of 1945. The difficulty of defining sovereign equality is manifested by the circular explanation, also taken from the San Francisco formula, that this equality amounts to the enjoyment of 'the rights inherent in full sovereignty'.

\section{B. Sovereign Equality as a New Concept}

In isolation, the term 'sovereign equality of states' makes little sense. As an adjective, 'sovereign' means 'supreme, paramount, principal, greatest, most notable' or 'having superior or supreme rank or power'. ${ }^{52}$ Accordingly, 'sovereign' cannot meaningfully be applied to equality in terms of a state's quality of being equal with every other state. In the drafting history of the

${ }^{31}$ For text, see UNYB 1948-9 at 948 et seq. and 44 American Journal of International Law (1950), Suppl., at 15-8. For analysis, see Fassbender, 'Commentary', above n. 44.

${ }_{52}$ See Oxford English Dictionary, $2^{\text {nd }}$ ed., vol. xvi (1989) at 77 et seq. 
UN Charter, 'sovereign equality' was first used with regard to nations, not states, and the first formulation simply spoke of the 'principle of equality of nations'. ${ }^{53}$ When the term was applied to states, as the established holders of external sovereignty, the emphasis on equality in law was not changed, but supplemented with an adjective reminiscent of the traditional status of states in international law. The word 'sovereign' appeared, but not in formulations like 'the principle(s) of equality and sovereignty of states' or 'the principle of equal sovereignty', which were intentionally avoided.

At the San Francisco Conference, 'sovereign equality' was deliberately adopted as a 'new term'. ${ }^{54}$ Its purpose was clear: The idea of equality of states in law was given precedence over that of sovereignty by relegating the latter to the position of an attributive adjective merely modifying the noun 'equality'. In this combination, sovereignty was meant to exclude the legal superiority of any one state over another, but not a greater role played by the international community vis-à-vis all its members. ${ }^{55}$ The new term proved to be an accurate description of a development characterising the international legal order in the age of the League of Nations and, in particular, the UN: From the two elements (sovereignty and equality), 'sovereignty is in a process of progressive erosion, inasmuch as the international community places ever more constraints on the freedom of action of States'. We witness a 'development towards greater community discipline ... driven by a global change in the perception of how the right balance between individual State interests and interests of mankind as a whole should be established'. ${ }^{56}$

\section{Sovereign Equality as Constitutional Autonomy}

In an article entitled 'The Principle of Sovereign Equality of States as a Basis for International Organisation' written in 1944, Hans Kelsen defined sover-
eignty as follows:

53 A first draft of the Moscow Declaration (see above n. 40) made in the US State Department had referred to an organisation 'based upon the principles of equality of nations and of universal membership'. It was later revised to read 'based on the principle of the sovereign equality of all nations', with the intention to indicate that the equality referred to was legal rather than the United States 1940-5 (WE Muther, A History of the United Nations Charter: The Role of the United States 1940-5 (Washington, DC, The Brookings Institution, 1958) at 111, 120.
s4 See the statement of the meaning of the ne Rapporteur of Committee 1, discussing 'amendments to determine subject, it passed the article 'sovereign equality": "When the Committee was considering this equality' was kept as Commission I, 15 June 1945; VI UNCIO 65 . Verbatim Minutes of Second Meeting of ss See B Fassbender 15 June 1945; VI UNCIO 65 et seqq., at 69 (emphasis added).

Perspective (The Hague, Kluwer Council Reform and the Right of Veto: A Constitutional ${ }_{56}$ See C Tomuschat, 'Obligations Arising for States 1998 ) at 109 et seq.

Recueil des Cours (1993) 195 at 292 . 
'[S]overeignty of the States, as subjects of international law, is the legal authority of the States under the authority of international law ... [T] he State is then sovereign when it is subjected only to international law, not to the national law of any other State. Consequently, the State's sovereignty under international law is its legal independence from other States. ${ }^{, 57}$

In other words, sovereignty is a collective or umbrella term, denoting the rights which, at a given time, a state is accorded by international law, and the duties imposed upon it by that same law. These specific ('sovereign') rights and duties constitute 'sovereignty'; they do not 'flow from' it. . $^{58}$ Sovereignty is the legal status of a state as defined (and not only 'protected' $)^{59}$ by international law. ${ }^{60}$ Accordingly, sovereignty is neither 'natural' nor static. In a process that has placed ever more constraints on the freedom of action of states, its substance has changed, and will further change in the future. For that reason, the unspecific and open-ended definitions of the San Francisco statement ${ }^{61}$ and the Friendly Relations Declaration, ${ }^{62}$ which at first glance seemed rather unsatisfactory, are fully accurate.

Under the rule of the UN Charter, the most important limitation of the rights formerly collectively addressed as sovereignty is the abolition of the jus ad bellum, or the right to wage war against another state. The Charter has put the international use of force under the exclusive control of the Security Council, the only exception being a state's temporary right to selfdefence according to Art. 51 of the Charter. In the words of FH Hinsley, this acceptance by states that war has ceased to be a legalised form of force constitutes 'a greater displacement of assumptions about relations between states than any that has ever taken place' since the rise of the state in human

\footnotetext{
57 See H Kelsen, 53 Yale Law Journal (1944) 207 at 208 (emphasis added). See also id., Principles of International Law (New York, Rinehart, 1952) at 155-7, 438-4, and id., "The Draft Declaration on Rights and Duties of States: Critical Remarks', 44 American Journal of International Law (1950) 259 at 268 et seq., 276.

${ }_{s 8}$ See also IL Claude, Jr., 'Foreword', in MR Fowler \& JM Bunck, Law, Power, and the Sovereign State: The Evolution and Application of the Concept of Sovereignty (University Park, PA, Pennsylvania State University Press, 1995), at x: Sovereignty 'is the essential indicator of the currently asserted and currently accepted implications of the status enjoyed by the units that give the system its multistate character: the rights, immunities, responsibilities, and limitations attributed to states.'

${ }_{s 9}$ But see H Steinberger, 'Sovereignty', in iv Encyclopedia of Public International Law (above n. 31), 500 at 518: 'As a juridical status protected by international law, [sovereignty] is embedded within the normative order of this law.'

${ }^{60}$ See also L Wildhaber, 'Sovereignty and International Law', in RStJ Macdonald \& DM Johnston (eds.), The Structure and Process of International Law: Essays in Legal Philosophy, Doctrine and Theory (Dordrecht, Martinus Nijhoff, 1986), 425 at 441: 'Authoritative writers agree that sovereignty is a relative notion, variable in the course of times, adaptable to new situations and exigencies, a discretionary freedom within, and not from, international law.' (Emphasis added.)

${ }^{61}$ See above text accompanying n. 48.

62 See above text following n. 49.
} 


\section{Sovereignty and Constitutionalism in International Law}

history. ${ }^{63}$ Today, the Charter's ban on the use of force is understood not so much as a limitation of sovereignty but as a necessary prerequisite for a de facto enjoyment of sovereign equality by states. A state's sovereign equality depends on a comprehensive prohibition of the use of force and on an effective mechanism to implement and enforce this prohibition. ${ }^{64}$ An equally important limitation of traditional sovereignty is the obligation of any state to protect the fundamental rights of all individuals subject to its jurisdiction, and the concomitant legal interest of the international community and all its members in their protection.

'If mankind is to achieve a more effective international organisation [...] the development must be from international towards constitutional law' ${ }^{6.5}$ Quite in line with this remark by W Friedmann, a more recent school of thought in international law understands the development of the law of nations, since the foundation of the League in 1919, as a process of constitutionalisation. ${ }^{66}$ The adoption of the Covenant and, later, the UN Charter is seen as a gradual effort to give the international community a constitution expressing systematically and in writing its fundamental values and the rules and procedures which shall protect them, so that the peaceful coexistence and cooperation of all nations of the world is ensured. The international community is not just perceived as a sum, or addition, of the interests of the individual states but as an entity committed to humankind as a whole, having its own legal personality and purposes which it can set against the opinion and action of a recalcitrant state ${ }^{67}$ This constitutional approach to international law seeks to reestablish a category of superior norms based on the collective will of the international community as a whole. The approach recognises a hierarchy of rules of international law in which those rules having the quality of constitutional law of the international community enjoy the highest rank and greatest firmness. At the same time, the notion of constitution takes up elements of organisation and

\footnotetext{
${ }^{63}$ See Hinsley, above n. 2, at 232.

${ }^{64}$ See Fassbender, UN Security Council Reform, above n. 55, at 111 et seq.

${ }^{65}$ See Friedmann, above n. 7, at 113 et seq. (with reference to the evolution of the European Communities as a possible 'prototype of developments that may ... eventually extend to the international community as a whole').

${ }^{66}$ For an analysis of the different constitutional concepts, see, in particular, P-M Dupuy, 'The Constitutional Dimension of the Charter of the United Nations Revisited', 1 Max Planck Yearbook on United Nations Law (1997) 1; B Fassbender, 'The United Nations Charter as Constitution of the International Community', 36 Columbia Journal of Transnational Law (1998) 529 at 538-68; A Paulus, Die internationale Gemeinschaft im Völkerrecht (Munich, $\mathrm{CH}$ Beck, 2001) at 285-328; R Kolb, Théorie du ius cogens international. Essai de relecture $d u$ concept (Paris, Presses Universitaires de France, 2001) at 100-8 (with an emphasis on the doctrinal history).

${ }^{67}$ See Tomuschat, 'Obligations', above n. 56, at 209-40; Simma, 'From Bilateralism', above n. 19, at 229-84. For a comprehensive study of the idea and reality of the international community in contemporary international law, see Paulus, Die internationale Gemeinschaft (above n. 61).
} 
institutionalisation characteristic of modern state constitutions. It is this constitutional view of the present international legal order which, following Kelsen's approach, leads to an understanding of sovereign equality that is in accordance with an orientation, so strongly strengthened in the past fifty years, of the individual state towards community values and goals: Sovereign equality is the legal authority and autonomy of a state as defined and guaranteed by the constitution of the international community. It denotes the entitlement of a state, and the people constituting it, to autonomous development and self-responsibility within the limits set by international law.

\section{5. 'SOVEREIGN RIGHTS' OF STATES UNDER THE CONSTITUTION OF THE INTERNATIONAL COMMUNITY}

That legal equality of states is the gist of the principle of sovereign equality was already emphasised in the proceedings of the San Francisco Conference as well as in the Friendly Relations Declaration of $1970,{ }^{68}$ which opens its explanation of the principle, it will be recalled, with the words: 'All States ... have equal rights and duties and are equal members of the international community, notwithstanding differences of an economic, social, political or other nature.' One may add: notwithstanding, in particular, differences in the size of territory and population, and in political, economic and military power.

But what exactly are those 'equal rights and duties'? In the words of Christian Tomuschat, 'every State, large or small, enjoys the rights which international law grants to States as subjects of international law' ${ }^{69}$ As equality as such does not, and cannot, define what these rights are, we are referred back to the above definition of the sovereign equality of states under the authority of international law. Accordingly, equal rights are the 'sovereign' rights equally enjoyed by states, as defined by international law or, more exactly, the constitution of the international community. If at times we speak of sovereignty, and then again of equality, we in fact address the same legally defined status of states. What differs is only the perspective, or the accent which is placed either on the autonomy of a state, understood as its legally defined capacity for self-determination, or its status in relation to that of other members of the international community and that community itself. Understood this way, the principle of 'sovereign equality' is indeed an apt representation of the identity of 'sovereignty' and 'equality' of states in the age of the United Nations.

\footnotetext{
${ }^{68}$ See above text accompanying n. 49.

${ }^{69}$ See C Tomuschat, 'International Law: Ensuring the Survival of Mankind on the Eve of a New Century', 281 Recueil des Cours (1999) 1 at 189.
} 


\section{Sovereignty and Constitutionalism in International Law}

In accordance with these two perspectives, the 'sovereign rights' presently accorded to states by international constitutional law are, first, the legal protection of a state's autonomy as a space of self-determination and, secondly, rights ensuring a state's equal membership in the international community. None of these rights 'flow' or 'derive from' sovereignty, equality, or sovereign equality as legal concepts or super-norms. On the contrary, it is they, as rights defined by norms of the positive constitutional law of the international community, that make up what can be addressed as the 'sovereignty', 'equality', or 'sovereign equality' of states.

\section{A. Rights Protecting Constitutional Autonomy}

As regards the constitutional rights in the service of state autonomy, a state is protected by the prohibition of the threat or use of force (Art. 2(4) of the UN Charter). If, nevertheless, an armed attack occurs, the attacked state has the right of individual or collective self-defense until the Security Council has taken the measures necessary to maintain international peace and security (Art. 51). A state is further protected by the duty of the other states and the organised international community not to intervene in matters within its domestic jurisdiction. ${ }^{70}$

'A prohibited intervention must ... be one bearing on matters in which each State is permitted, by the principle of State sovereignty, to decide freely. ${ }^{{ }^{71}}$

Within the limits of international law, a state is entitled freely to determine its constitution and its political, social, economic and cultural order, which the other members of the international community must respect. If a state has a democratic constitution, its sovereignty protects a space of democratic self-determination. A sovereign state possesses jurisdiction over its citizens as well as over foreigners present in its territory (albeit limited by the obligation to safeguard their fundamental human rights and freedoms), and an exclusive power to use physical force to enforce its law within its territory. Further, a sovereign state has the right to determine its future legal status. It can, for instance, decide to form a union with, or to become an integral part of, another state, and thus relinquish its sovereignty. The details of all these rights and entitlements are controversial and dynamic, and must be studied with the help of treatises, manuals and casebooks of international law.

\footnotetext{
${ }^{70}$ For an overview of the contemporary rules of jurisdiction, in particular extraterritorial jurisdiction, see ibid. at 195-202.

${ }_{71}$ See the Nicaragua judgment of the International Court of Justice, ICJ Reports (1986) 14 at 108 .
} 


\section{B. Rights of Participation in the International Community}

The rights ensuring equal membership in the international community are principally rights of participation in the exercise of the functions of governance of that community, that is to say, in making and applying international law and adjudicating international legal claims. ${ }^{72}$ Traditional formal rights of participation - which are also means of pursuing and enforcing the substantive rights of autonomy-are the rights to conclude international treaties, to send and receive diplomatic envoys (right of legation), and to make diplomatic claims. A sovereign state enjoys a principally unlimited international legal personality and capacity to perform international legal acts. This distinguishes it from other subjects of international law, in particular intergovernmental organisations, which have a limited legal personality defined by the respective founding treaty. It used to be said that sovereign states are the only 'born' or 'natural' persons of international law, whereas all others are 'made' in the sense that they are brought into existence as legal persons by an action of states.

According to traditional doctrine, equality in legal status does not mean that every state is entitled to join treaties purporting to set up universal regimes, or law-making treaties laying down general rules of conduct for an unspecified number of states. Even the organised international community is said to be under no obligation to open access to the treaties drawn up under its auspices to all states. ${ }^{73}$ This view is highly objectionable. ${ }^{74}$ It means that individual states can be excluded from treaties effectively serving as legislative instruments of the international community. In fact, if a certain subject has been dealt with in a multilateral treaty with general or even quasi-universal participation, an excluded state is effectively barred from regulating this subject by means of bilateral or multilateral treaties. To that extent, that state is actually deprived of its treaty-making capacity. It is submitted that this is incompatible with the idea of equal membership of all states in the international community - an idea suggesting, contrary to the above, a right of every state not only to join such general treaties but also to participate in their negotiation. ${ }^{75}$ In accordance with this view, Art. 10 of

\footnotetext{
72 For the system of governance established by the UN Charter, see Fassbender, Columbia Journal of Transnational Law, above n. 66, at 574-6.

${ }_{73}$ See Tomuschat, 'International Law', above n. 69, at 189 et seq., and for the category of 'law-making treaties' R Jennings \& A Watts (eds.), Oppenheim's International Law, vol. 1, $9^{\text {th }}$ ed. (London and New York, Longman, 1992); at 1203-6. In its 1962 Draft Articles on the Law of Treaties the International Law Commission defined a 'general multilateral treaty' as 'a multilateral treaty which concerns general norms of international law or deals with matters of general interest to States as a whole'.

${ }_{74}$ Cf. Simma, 'From Bilateralism', above n. 19, at 325 et seq.

${ }^{75}$ See, e.g., V Pechota, 'Equality: Political Justice in an Unequal World', in The Structure and Process of International Law, above n. 58, 453 at 467.
} 
the Charter of Economic Rights and Duties of States ${ }^{76}$ provides that 'as equal members of the international community, [all States] have the right to participate fully and effectively in the international decision-making process in the solution of world economic, financial and monetary problems'.

Today, all states are equally obliged to heed the rules of the UN Charter. Consequently, all states are also equally entitled to membership in the permanent organs of the international community. The 'principle of universality' of the UN follows from the constitutional character of the Charter." Art. 4(1) of the Charter must therefore be read as entitling every sovereign and 'peace-loving' state to membership in the United Nations. ${ }^{78}$ The latter requirement is met if a state credibly accepts the fundamental constitutional principles of the international community as enshrined in the Charter and other instruments. This right to membership is especially momentous if one recalls that today 'in most instances membership in the United Nations determines the existence of a State, irrespective of any additional unilateral acts of recognition on the part of States' ${ }^{79}$ Since the 'package deal' of 1955, UN practice has generally recognised the constitutional right of states to UN membership.

A (temporary) suspension of a state which has seriously violated the rules of the Charter 'from the exercise of the rights and privileges of [UN] membership' (Art. 5 of the Charter) is acceptable from a constitutional point of view. ${ }^{80}$ However, it seems inadmissible permanently to exclude a state from the organic structure of the community as established by the Charter. To prevent a state permanently from participating in the work of the community organs is incompatible with the very idea of an international community living under a constitution. In fact, in the history of the UN, not a single member state has been expelled from the Organisation.

\section{Sovereign Equality in the United Nations}

The records of the San Francisco Conference and the preceding diplomatic negotiations demonstrate that the prerogatives which the leading powers were given in the UN Charter-in particular permanent membership in the

\footnotetext{
76 General Assembly Res. 3281 (XXIX), 12 December 1974; UNYB 1974 at 402.

77 See Fassbender, Columbia Journal of Transnational Law, above n. 66, at 610-3, and id., 'Universality', in H Volger (ed.), A Concise Encyclopedia of the United Nations (The Hague, Kluwer Law International, 2002) at 576-8.

${ }_{78}$ See Conditions of Admission of a State to Membership in the UN International Court of Justice Reports (1947-8) 57 at 71 (indiv. opinion Alvarez). See also the amendments and comments of states concerning UN membership submitted at the San Francisco Conference: Department of State (ed.), The United Nations Conference on International Organization: Selected Documents (Washington, D.C., Government Printing Office, 1946), at 111 et seq.

${ }^{79}$ See J Dugard, Recognition and the United Nations (Cambridge, Grotius, 1987), at 167.

${ }^{80}$ See Fassbender, Columbia Journal of Transnational Law, above n. 66, at 613-5.
} 
Security Council and the right of veto according to Art. 27(3)--were regarded as painful, albeit necessary, exceptions to a true equality of status of all member states in the new Organisation. So much was even admitted by the major powers themselves. The first leading commentary on the Charter could do no more than state the contradiction between the promise of Art. 2(1) and the provisions of Arts. 23(1) and 27(3) by saying:

'In the Charter the principle of equal legal rights is recognised ... The Charter does, however, recognise the inequality of Members in respect to power and political influence by according the 'Great Powers' permanent membership in the Security Council and the so-called 'right of veto'. ${ }^{81}$

As far as a contradiction is recognised between the terms of the Charter on the one hand, and sovereign equality as a principle of general international law on the other, a purely contractual view of the Charter has no difficulty in resolving it: It is exactly their sovereignty which is said to enable states to enter into international agreements which may, or may not, provide for unequal rights and obligations of the parties. This argumentation, however, is no longer viable if the Charter is seen as the constitution of the international community. ${ }^{82}$ Since this view dissolves the dualism of 'general international law' and the law of the Charter, ${ }^{83}$ exceptions to legal equality in the latter can no longer be justified by having recourse to the former category. Instead, an attempt to read the Charter in a way that reconciles its seemingly contradictory pronouncements is necessary.

An answer to the problem may be sought by recalling once again that in the Charter the traditional concepts of sovereignty and equality of states were replaced with a new principle-with a different, 'community-oriented' content-that of sovereign equality. In line with this orientation, ' $[t]$ he rule of state equality could be understood as coherently modified by a rational principle of distinction: that states bearing the greatest institutional responsibility should also have the greatest say in critical disputes' ${ }^{84}$ In the form of sovereign equality, formal equality of states has been qualified to the extent necessary for achieving the common interests of the international community. ${ }^{85}$ This common interest requires furnishing certain states,

${ }^{81}$ See LM Goodrich \& E Hambro, Charter of the United Nations: Commentary and Documents $2^{\text {nd }}$ edition (Boston, World Peace Foundation, 1949), at 100. Similarly PC Jessup, A Modern Law of Nations: An Introduction (New York, Macmillan, 1948), at 30.

${ }^{82}$ For a fuller exposition of the following reasoning, see Fassbender, UN Security Council Reform, above n. 55, at 287-95.

${ }^{83}$ See Fassbender, Columbia Journal of Transnational Law, above n. 66, at 585-8.

${ }^{84}$ See TM Franck, The Power of Legitimacy Among Nations (Oxford, Oxford University Press, 1990), at 177.

${ }^{85}$ For an analysis of the place and role of the 'common interest' in current international law, see B Fassbender, 'Zwischen Staatsräson und Gemeinschaftsbindung: Zur Gemeinwohlorientierung des Völkerrechts der Gegenwart', in H Münkler \& K Fischer (eds.), Gemeinwoblkonkretisierungen und Gemeinsinnerwartungen: Zur Relevanz unbestimmter Rechtsbegriffe (Berlin, Akademie Verlag, 2002). 


\section{Sovereignty and Constitutionalism in International Law}

whose extraordinary commitment to community goals is indispensable, with special rights if otherwise their support cannot be enlisted. ${ }^{86}$ It must also be taken into consideration that the prohibition of the use of force in international relations is a prerequisite for an enjoyment of sovereign equality by states, ${ }^{87}$ and that, in turn, the effectiveness of this prohibition depends on a working institutional arrangement-a necessary part of which is the special position given to the major powers in the Security Council.

Thus the principle of sovereign equality recognises as necessary a relation between responsibilities (or duties) and rights in an institutional structure established with the principal purpose of maintaining international peace and security ( $c f$. Art. 1(1) of the Charter). At San Francisco, this consideration of responsibility in the understanding of equality found expression in Colombia's proposal for a preamble of the Charter as follows:

'The High Contracting Parties,

$\cdots$,

Agree that the following are necessary:

‥

VI. To establish the principle of the equality before Law of all States, whatever their population, their wealth, their strength or their territorial extent, but to admit, at the same time, that the Great Powers, because they have greater international responsibility, must likewise exert a greater functional influence in the organization of the world. ${ }^{88}$

\section{Sovereign Equality of States in Their Mutual Relations}

In their mutual relations, states must treat each other as equals. The practical importance of that principle is, however, limited. In spite of several provisions in the UN Charter about the international cooperation of states (cf. Arts. 1(3), 11, 13, 56), and the 'duty of States to co-operate with one another .... in the various spheres of international relations' proclaimed in the Friendly Relations Declaration, ${ }^{89}$ states are still considered free not to maintain relations (of a diplomatic, political, economic or other character) with other states at all. If such relations are maintained, a state may differentiate between states in the treatment it accords to them..$^{90}$ In particular,

\footnotetext{
${ }^{86}$ Colin Warbrick speaks of a 'functional' reason for providing certain states with a preferential status. See C Warbrick, 'The Principle of Sovereign Equality', in V Lowe \& C Warbrick (eds.), The United Nations and the Principles of International Law: Essays in Memory of Michael Akeburst (London and New York, Routledge, 1994), 204 at 211, 215.

${ }_{87}$ See above text accompanying n. 64.

${ }^{88}$ See proposal of May 11, 1945; VI UNCIO at 528.

${ }^{89}$ See above n. 49. See also many other resolutions of the General Assembly to that effect, for instance the Charter of Economic Rights and Duties of States (above n. 76).

${ }^{90}$ See Oppenheim's International Law, above n. 73, at 376-9. However, the authors add that 'in some particular respects a rule of non-discrimination may exist, within limits which are not clear'.
} 
states can, when entering into international treaties, agree on an unequal treatment of parties to the treaty. Trade agreements can, for instance, provide for an unequal access to the respective markets. Likewise, there is no general right to most-favoured-nation treatment. When establishing international organisations, states can arrange for differentiated responsibilities and rules of weighted voting which take account of the factual importance of a country in a certain respect (like its economic strength, or its importance as a maritime power). In short, sovereign equality is not a rule of jus cogens (as defined by Art. 53 of the 1969 Vienna Convention on the Law of Treaties) $)^{91}$ from which no derogation could be permitted, ${ }^{92}$ notwithstanding its character as a fundamental principle of the constitutional law of the international community.

Therefore, in the relations between states, the principle of sovereign equality remains essentially confined to its formal dimension. ${ }^{93}$ It means that ' $[\mathrm{e}] \mathrm{ach}$ State has the duty to respect the personality of other States', as the Friendly Relations Declaration puts it. A procedural consequence is emphasised by the Manila Declaration on the Peaceful Settlement of Disputes of 1982, which formulates the rule that '[i]nternational disputes shall be settled on the basis of the sovereign equality of States'. ${ }^{94}$

In addition, states are obliged to comply, in their relations with each other, with a number of specific 'rules of abstention' ${ }^{95}$ which —as in a mirror image-arise from the rights protecting the constitutional autonomy of states. In fact, the autonomy accorded to states by the constitution of the international community only becomes effective because of corresponding obligations imposed on the same states. The rules prohibiting the threat or use of force, and intervention in matters within the domestic jurisdiction of other states, and the right to self-determination imply, on the one hand, rights of any one state vis-à-vis the other states-i.e. 'sovereign rights' intended to protect a state's autonomy under international law. On the other hand, the same rules constitute obligations on every state vis-à-vis any other state, obligations intended to ensure the sovereign equality of states in their mutual relations.

Whether, and to what extent, these obligations are actually fulfilled is, of course, a different question. It is the answer to that question which decides

\footnotetext{
${ }^{91}$ For text, see 1155 UNTS 331, 63 American Journal of International Law (1969) 875, 8 International Legal Materials (1969) 679.

${ }_{92}$ See Tomuschat, 'International Law', above n. 69, at 193; Wildhaber, above n. 60, at 442, 444; A Cassese, International Law (Oxford, Oxford University Press, 2001), at 110. Cf. Kolb, above n. 66, at 115 et seq., 172-81 ('la nécessité de distinguer entre ius cogens et ordre public international')

${ }^{93}$ See Tomuschat ibid.

94 Annex to General Assembly Res. 37/10, 15 November 1982, para. I 3; UNYB 1982 at 1372.

${ }^{95}$ For this term, coined by W Friedmann, see above text accompanying n. 7.
} 


\section{Sovereignty and Constitutionalism in International Law}

how wide and deep the gap is between international law and reality, or the legal ownership and the real holding of sovereign equality. It is obvious that today the autonomy actually enjoyed by the large majority of states almost entirely depends on the functioning of an organised international community which patiently strives

'to replace unlimited and, ultimately, destructive national competition and freedom of action by international co-operation'. ${ }^{96}$

\section{E. Sovereign Equality of States and Supranationalism}

Under present international law, sovereign equality (namely the rights of participation and rights protecting autonomy) is only enjoyed by sovereign states and not by intergovernmental or 'supranational' organisations, even if they have been granted far-reaching governmental powers and approach a state-like quality. As long as such an organisation has not constituted itself, and has not been recognised, as a 'sovereign state', its status in international law remains a derivative one. Internally, i.e. in the relations between the organisation and its member states, sovereignty may be 'divided', 'shared' or 'mixed', but in international law an all-or-nothing approach to sovereignty is still operative. Doctrine and legal practice follow the route once fixed to identify the 'seat of sovereignty' in federal associations and unions of states (the distinction between Bundesstaat and Staatenbund). ${ }^{97}$ However, while it was in the past political communities below a 'central' level of territorial government that were declared nonsovereign on the basis of this theory, it is now the case that communities are vaulting the 'sovereign' states and partially replacing them in the exercise of governmental functions.

It is a characteristic shortcoming of the present constitution of the international community that it defines, in the form of 'sovereign equality', the constitutional status of ('sovereign') states but not that of international or supranational organisations, despite the importance they have won in the international legal order. Instead, it is still left to the member states of such an organisation to define in each case its international legal position. On the other hand, it is testimony to the dissolution of 'sovereignty' traditionally understood in a number of variable ('sovereign') rights that a body like the European Union has little difficulty in asserting, in its relations with nonmember states, the rights necessary for the performance of its functions. In other words, in its regular business the EU does not miss 'equal sovereignty' all that much.

${ }^{96}$ See W Friedmann, 'General Course in Public International Law', 127 Recueil des Cours (1969) 39 at 243.

${ }_{97}$ See Merriam, above n. 2, ch. X (pp. 185-216) about 'federalism and continental theory'. 


\section{SOVEREIGN EQUALITY IN AN AGE OF GLOBALISATION}

Some authors argue that contemporary international law has surpassed Friedmann's 'law of cooperation'. To Tomuschat, for instance, today the international legal order is in the third stage of its development: the law of coexistence and the law of cooperation are followed by a period of 'international law as a comprehensive blueprint for social life', the chief characteristic of which is a 'further intrusion of international law into matters previously thought to be shielded from any outside interference'. In particular, the author emphasises the obligations imposed on states with regard to human rights, democracy as a form of government, and 'good governance'. ${ }^{98}$ He concludes that international law, '[i]nstead of being a set of rules limiting and guiding States in their foreign policies, ... has become a multi-faceted body of law that permeates all fields of life ... [W] e are facing today a totally new international law which has lost all of its former inhibitions. ${ }^{.99}$ Accordingly, it is stated that, juridically, little remains of the traditional sovereignty of states.

As regards the principle of sovereign equality of states, the development described in those terms can be explained as a further reduction of the space of autonomy accorded to states by international law. In other words, the boundary between matters left to the exclusive control of states, and those which are a concern of the international community and can be regulated by international law, has moved further, extending again the space of international competence. This shift does not, however, simply amount to a greater restriction of the sovereign equality of states. Rather, it involves an increase in importance of the 'second pillar' of sovereign equality, namely the rights of participation in the international community. A certain loss of autonomy of states-in particular in the legislative field, but also with regard to the executive and the judicial functions-can thus be compensated for by increased participatory rights at the international level. ${ }^{100}$

However, contemporary international law is also regarded as being challenged from a different perspective:

[G]lobalisation has rendered the traditional assumption of an inter-statal society problematic ... [It] seems to diminish the role of the state and to open up international society for new actors, both economic and altruistic non-governmental organisations ... Some observers . . . see the state squeezed between globalisation from above (business) and below (NGOs)... [G]lobalisation has also curbed the

\footnotetext{
${ }_{98}$ See Tomuschat, 'International Law', above n. 69, at 63-70.

${ }^{99}$ Ibid. at 70 et seq.

100 This process is reminiscent of the constitutional development in federal states like Germany and Switzerland where the individual states (Länder, Kantone) have lost legislative powers but won participatory rights at the federal level. Similarly, the loss of independent powers of EU member states to the advantage of the Union is said to be (at least partially) offset by a gain of rights of participation at the EU level.
} 
belief in the benefit of governmental institutions, be they national or global. Liberals and Neoliberals demand a reconstruction of international law on an interindividual basis.' ${ }^{101}$

Whether these partially contradictory trends and aspirations-which are discussed mainly in the current international relations literature-will prevail is as yet uncertain. ${ }^{102}$ But we may well be moving in the direction of a more diverse or fragmented international order in which states no longer play the leading role-and in which international law as hitherto defined (i.e. law principally governing the intercourse between states) can no longer claim to be the primary regulatory code of international affairs. ${ }^{103}$ Perhaps there is indeed an international system of 'interlocking communities' ${ }^{104}$ looming on the horizon, made up of individuals, organisations (economic and others) and states with overlapping memberships and allegiances. ${ }^{105}$

For the principle of sovereign equality, as a cornerstone of contemporary international law, such a development would raise complex problems which can only be indicated here. Sovereign equality is a principle which applies to the relations between states and the organised international community, and between states in their mutual relations. If the relations between these 'public' actors become less important because of privatisation, deregulation (on the national or international level) and a proliferation of other international actors, the scope of application of the principle of sovereign equality diminishes accordingly. Within its respective autonomous space, each state is free to remove regulatory controls from economic, social and other activ-

${ }^{101}$ See Paulus, above n. 66, at 439, 441, 443. For studies focusing on the issue of sovereignty which generally support this description, see, e.g., RBJ Walker \& SH Mendlovitz (eds.), Contending Sovereignties: Redefining Political Community (Boulder, Col., Rienner, 1990); JA Camilleri \& J Falk, The End of Sovereignty? The Politics of a Shrinking and Fragmenting World (Aldershot, Elgar, 1992); MSM Mahmoud, 'Mondialisation et souveraineté de l'État', 123 Journal du droit international (1996) 611; S Sassen, Losing Control? Sovereignty in an Age of Globalization (New York, Columbia University Press, 1996); B Badie, Un monde sans souveraineté. Les États entre ruse et responsabilité (Paris, Fayard, 1999). See also WH Reinicke, Global Public Policy: Governing without Government? (Washington, DC, Brookings Institution Press, 1998).

${ }^{102}$ For a cautious prognosis, based on historical analysis, 'that in many respects the contemporary state system is becoming more firmly entrenched rather than declining', see H Spruyt, The Sovereign State and Its Competitors: An Analysis of Systems Change (Princeton, NJ, Princeton University Press, 1994) at 192. For a similar appraisal from a legal point of view, see N Schrijver, 'The Changing Nature of State Sovereignty', 70 British Year Book of International Law (1999) 65 at 95-8. For a more determined judgment, see Krasner, above n. 2, at 223: 'There is no evidence that globalisation has systematically undermined state control or led to the homogenization of policies and structures. In fact, globalization and state activity have moved in tandem.'

${ }^{103}$ For a sketch of an international legal framework based on a greater diversity of actors, see C Schreuer, 'The Waning of the Sovereign State: Towards a New Paradigm for International Law?', 4 European Journal of International Law (1993) 447.

${ }_{104}$ For this phrase, see J Thompson, Justice and World Order: A Philosophical Inquiry (London and New York, Routledge, 1992), at 171, 180, 183. Cf. Paulus, above n. 61, at 161 et seq.

${ }^{105}$ See Paulus, ibid. at 446. 
ities; acting jointly, states may also engage in 'international deregulation'. It is as yet unclear what forms of new structures and decision-making processes could emerge under such changed conditions. Perhaps the concept of equal rights of peoples, already familiar to international law in connection with the right of self-determination, could take over some of the functions until now performed by the principle of sovereign equality of states-especially that of giving individuals and groups the possibility of ' $m a k$ [ing] a difference in a structured political space'. ${ }^{106}$

\section{THE UNTAMED SIDE OF SOVEREIGNTY}

In international law, we concern ourselves with sovereignty as a legal notion. We engage in an effort to define its contents and borders, and to relate it coherently to other notions, principles and rules of international law. Why has this, when we look back on the literature of the past, always been so difficult, much more so than in the case of other concepts of international law?

Since it was invented, sovereignty has had a strong political dimensionit has, in fact, been more about making claims for a change of the status $q u o$, or claims to power, than a careful observation of legal rules. JL Brierly once spoke of 'the impulse to power that we call sovereignty when we see it manifested in the conduct of states' ${ }^{\prime}{ }^{107}$ The clearest manifestation of that impulse is still war. War, the historian Golo Mann once said, was the 'ultima ratio of kings'; 'there were no kings without war'. ${ }^{108}$ The UN Charter notwithstanding, the bond between sovereign statehood and war has remained close.

The international law of coexistence was a rather loosely woven fabric, offering states many opportunities for action not, or not strictly, based on the authority of law. In contrast, the present international legal order aspires comprehensively to regulate social life on all levels of governance. In this transformed environment, the sovereignty of states stands out as a legal concept which exposes one of its flanks to politics and power. 'It has

\footnotetext{
${ }^{106}$ For a well-founded warning that discarding sovereignty in favour of a multifaceted, functional-contractual system of rule-making in a diverse international community could lead to larger inequalities in and between societies, and a legitimisation of 'interventionist or otherwise coercive activities in other countries that reflect struggles and dilemmas in politics in the West', see B Kingsbury, 'Sovereignty and Inequality', 9 European Journal of International Law (1998) 599.

${ }^{107}$ See JL Brierly, 'The Sovereign State Today' (1949), in id., The Basis of Obligation in International Law and Other Papers $\mathrm{H}$ Lauterpacht \& CHM Waldock (eds), (Oxford, Clarendon Press, 1958), 348 at 352.

${ }_{108}$ See G Mann, 'Krieg', in id. \& H Pross, Aussenpolitik (Frankfurt am Main, Fischer, 1957), 143 at 159 .
} 


\section{Sovereignty and Constitutionalism in International Law}

frequently had to serve as a juridical cover to mere power politics. ${ }^{109}$ In other cases, it provided, or rather channelled, legal arguments which, having found acceptance by other states, eventually led to a change in the law. What has made the concept in that respect especially convenient (or, in a different perspective, vulnerable) is a certain fuzziness resulting from its long history and the many different uses made of it in the past. In particular, sovereignty's original meaning as 'supreme authority' has asserted an indistinct presence, notwithstanding the efforts-mere attempts as well as achievements-of legal science to domesticate the notion and define it as the legal autonomy of a state under international law. Sovereignty still

'stands for freedom of action by states when the need is for central coordination and control, and it evokes the fear of unpredictable and irresponsible state behaviour instead of progress toward the international rule of law'.10

There is an untamed side of sovereignty-characteristic, one could say, of the international system as a political system sui generis- ${ }^{111}$ which one can deplore or disapprove of, but which to ignore in legal analysis would be a mistake.

In the late 1920s, Kelsen referred to his time as a transitional period in the history of international law, and saw this character reflected in the 'contradictions of an international legal theory which in an almost tragic conflict aspires to the height of a universal legal community erected above the individual states but, at the same time, remains a captive of the sphere of power of the sovereign state'. ${ }^{12}$ Almost forty years later, W Friedmann arrived at a very similar conclusion when he said:

'In terms of objectives, powers, legal structure and scope, the present state of international organisation presents an extremely complex picture. It reflects the state of a society that is both desperately clinging to the legal and political symbols of national sovereignty and being pushed towards the pursuit of common needs and goals that can be achieved only by a steadily intensifying degree of international organisation. ${ }^{213}$

And where do we stand today? The UN Charter was a bold effort to end the transitional period recognised by Kelsen in favour of a lasting international constitutional order no longer dependent on the capriciousness of sometimes well-meaning, sometimes egoistic states. But more than fifty years after the "constitutional moment ${ }^{\text {'114 }}$ which gave rise to the Charter, the

\footnotetext{
109 See Steinberger, above n. 59, at 501.

110 See Claude, above n. 58, at ix.

11 See Hinsley, above n. 2, at 229

112 See H Kelsen, Das Problem der Souveränität und die Theorie des Völkerrechts. Beitrag zu einer Reinen Rechtslebre (Tübingen, JCB Mohr (Paul Siebeck), $2^{\text {nd }}$ edition 1928), at 320.

${ }_{113}$ See Friedmann, The Changing Structure, above n. 7, at 293 et seq.

${ }_{114}$ The term is borrowed from B Ackerman, We the People: Foundations (Cambridge, Mass., and London, Harvard University Press, 1991), passim.
} 
contradictions have not disappeared. Behind sovereign equality, sovereignty lingers on. Or rather: Images of sovereignty constructed in past centuries remain, much longer than was expected, or hoped for, in 1945. It seems that the power of those images was underestimated, a power, admittedly, perhaps greater than that of sovereignty's tamed version. 